\title{
Meningkatkan Hasil Belajar IPA Menggunakan Model Think Pair Share Siswa Kelas X Tata Boga Smk Negeri 3 Blitar
}

\author{
Syayidati Islamiyati \\ SMKN 03 Blitar, Indonesia \\ Email: syayidati islamiyati@yahoo.co.id
}

\begin{abstract}
Abstrak: Penelitian ini bertujuan untuk mendeskripsikan penerapan pembelajaran model Think Pair Share yang dapat meningkatkan hasil belajar materi gaya, usaha, dan energi pada siswa kelas X Tata Boga 1 SMK Negeri 3 Blitar Tahun Pelajaran 2019/2020. Penelitian ini merupakan Penelitian Tindakan Kelas (PTK) dengan 2 siklus. Teknik analisis data yang digunakan meliputi reduksi data, penyajian data dan penarikan kesimpulan. Hasil penelitian menunjukkan bahwa pelaksanaan pembelajaran dengan metode Think Pair Share (TPS) ada peningkatan hasil belajar materi gaya, usaha, dan energi setelah dilakukan tindakan pembelajaran dengan model Think Pair Share (TPS), dimana

Tersedia Online di

http://journal.unublitar.ac.id/pendidika n/index.php/Riset_Konseptual

Sejarah Artikel

Diterima pada : 06-04-2020

Disetuji pada : 29-04-2020

Dipublikasikan pada : 30-04-2020

Kata Kunci:

IPA Terapan, Model Think Pair and Share

DOI:

http://doi.org/10.28926/riset_konseptual.v4i2. 218

pada siklus I tingkat ketuntasan belajar hanya mencapai 55,88\% dan pada siklus II menjadi $91,18 \%$. Disamping itu aktivitas guru dan siswa juga mengalami peningkatan dimana sebelumnya berkategori baik menjadi sangat baik. Begitu juga ketrampilan kooperatif dengan Think Pair Share (TPS), dari baik menjadi sangat baik.
\end{abstract}

\section{PENDAHULUAN}

IImu Pengetahuan Alam (IPA) Terapan merupakan mata pelajaran produktif dasar di Sekolah Menengah Kejuruan (SMK) Pariwisata, materi ini ditujukan untuk mengendalikan cara kerja alam. Contoh: menanam singkong, dan kemudian singkong tersebut dapat diolah menjadi berbagai macam makanan, misalnya kripik singkong. Trianto (2012) mengatakan bahwa hakikat IPA adalah ilmu pengetahuan yang mempelajari gejala-gejala melalui serangkaian proses yang dikenal dengan proses ilmiah yang dibangun atas dasar sikap ilmiah dan hasilnya terwujud sebagai produk ilmiah yang tersusun atas tiga komponen terpenting berupa konsep, prinsip dan teori yang berlaku secara universal.

Permendiknas Nomor 22 Tahun 2006 dikatakan bahwa IPA berhubungan dengan cara mencari tahu tentang alam secara sistematis. Pembelajarannya IPA menekankan pada pemberian pengalaman langsung kepada siswa serta pemahaman untuk mengembangkan kompetensi siswa agar mampu menjelajahi dan memahami alam sekitar secara mendalam dan ilmiah. Siswa lebih mudah mengingat pengetahuan yang diperoleh secara mandiri lebih lama dibandingkan dengan informasi yang diperoleh dengan mendengarkan cerita orang lain. Melalui pengalaman langsung dan proses menemukan secara mandiri, pengetahuan yang diperoleh akan lebih bermakna dan terpatri dalam diri siswa. Tapi di Sekolah Menengah Kejuruan (SMK) hal ini tidak bisa dilaksanakan (terutama untuk konsep dasar dari IPA) karena alat, bahan, dan laboratorium IPA tidak tersedia. Dengan IPA Terapan sebenarnya bisa langsung ke bengkel/ruang praktek masing-masing kompetensi keahlian, hal ini sering terkendala karena bengkel dipakai praktek untuk mata pelajaran C2 (Dasar Program Keahlian) dan C3 (Kompetensi Keahlian). IPA Terapan di SMK Pariwisata masuk kelompok C1 (Dasar Bidang Keahlian). 
Pada proses kegiatan belajar mengajar awal yang dilakukan, pembelajaran IPA di kelas X Tata Boga 1 SMK Negeri 3 Blitar masih menggunakan metode belajar konvensional sehingga suasana belajar terkesan kurang menarik dan didominasi oleh guru (teacher centered). Guru menyampaikan materi melalui metode ceramah dimana siswa duduk, mencatat dan mendengarkan apa yang disampaikan oleh guru serta mengerjakan soal-soal yang ada di buku. Guru hanya menggunakan media berupa buku dan tidak tampak menggunakan alat bantu atau media lainnya dalam menanamkan konsep-konsep IPA. Suasana pembelajaran tidak kondusif dan aktivitas siswa rendah sehingga kurang meningkatkan kreativitas siswa. Siswa kurang termotivasi untuk menyampaikan pendapat, ide, gagasan, pertanyaan dan kesulitankesulitan maupun hal-hal yang belum dipahami selama pembelajaran berlangsung.

Berdasarkan hasil analisis nilai ulangan harian pertama tentang besaran fisika, sekitar 35,29 siswa kelas X Tata Boga 1 SMK Negeri 3 Blitar yang mencapai nilai Kriteria Ketuntasan Minimal (KKM) yang ditetapkan yaitu 75. Ini berarti siswa yang tidak mencapai KKM 64,70 \%. Diperoleh nilai terendah 10 (diperoleh oleh siswa yang inklusi) dan nilai tertinggi 80. Rendahnya proses dan hasil belajar IPA Terapan di kelas $X$ ini disebabkan oleh beberapa faktor, diantaranya adalah penggunaan metode pembelajaran yang kurang tepat dan kurang menarik bagi siswa. Hal ini merupakan masalah yang harus segera diatasi sehingga diperlukan suatu solusi dengan menggunakan model pembelajaran yang tepat.

Supaya konsep dasar yang terbangun dalam pikiran siswa semakin kuat, maka dibutuhkan teman lain atau pasangan lain (pair) untuk berbagi (share) tentang apa yang tengah dipikirkannya, sehingga konsep yang mereka bangun benar-benar terbangun kuat dalam pikiran siswa. Model pembelajaran yang demikian dikenal sebagai model pembelajaran Think Pair Share (TPS). Model Think Pair Share merupakan salah satu model dari pendekatan pembelajaran kooperatif yang dikembangkan olah Frank Lyman dan rekan-rekan dari Universitas Maryland. Think Pair Share memiliki prosedur yang ditetapkan secara eksplisit untuk memberi siswa waktu lebih banyak untuk berpikir, menjawab dan saling membantu satu sama lain (Ibrahim, 2000). Dengan menggunakan cara seperti ini diharapkan siswa mempu bekerja sama, saling membantu dan saling bergantung pada kelompok-kelompok kecil secara kooperatif, sehingga dengan menggunakan pendekatan pembelajaran berbasis konstruktivis dan dengan model pembelajaran Think Pair Share (TPS) diharapkan hasil belajar yang terdiri dari kemampuan kognitif, afektif dan psikomotorik dapat meningkat.

Berdasarkan latar belakang masalah tersebut maka perlu dilakukan penelitian tindakan kelas dengan judul "Peningkatan Hasil Belajar IPA Terapan pada Materi Gaya, Usaha, dan Energi Melalui Model Pembelajaran Think Pair Share di Kelas X Tata Boga 1 SMK Negeri 3 Blitar". Dengan penelitian ini diharapkan dapat meningkatkan hasil belajar siswa dalam mata pelajaran IPA Terapan.

\section{METODE}

Penelitian Tindakan Kelas ini dilaksanakan di kelas X Tata Boga 1 SMK Negeri 3 Bllitar yang beralamat di Jalan Sudanco Supriadi No. 24 Kota Blitar. Dan IPA Terapan diberikan di Kelas $X$ untuk Bidang Keahlian Pariwisata. Untuk jadwal pembelajaran, SMK Negeri 3 Blitar menerapkan sistem blok. Pergantian jadwal setiap minggu, dimana jadwal dibagi menjadi 2 yaitu jadwal minggu ganjil dan minggu genap. Di kelas $X$ Tata Boga 1 mata pelajaran IPA Terapan ada di minggu ganjil, hari Selasa jam ke $1-3$ dan hari Jumat jam ke 1 - 3. Jadi pertemuan berikutnya ada setelah 2 minggu kemudian.

Subjek penelitian ini adalah guru (dalam hal ini peneliti) dan siswa kelas $X$ Tata Boga 1 SMK Negeri 3 Blitar pada semester ganjil tahun pelajaran 2019/2020. Jumlah siswa kelas X Tata Boga 1 adalah 34 anak yang terdiri dari 3 siswa laki-laki dan 31 siswa perempuan. 


\section{Paparan Data Siklus I}

\section{HASIL dan PEMBAHASAN}

Kegiatan yang dilakukan pada siklus I meliputi perencanaan, pelaksanaan, observasi dan refleksi. Pembelajaran Siklus I dilaksanakan 2 kali pertemuan, masingmasing pertemuan 3 jam pelajaran. Pada tindakan I ini guru menerapkan pembelajaran kooperatif model Think Pair Share pada materi gaya untuk pertemuan ke 1 dan usaha pada pertemuan ke 2 .

Pelaksanaan tindakan dilakukan berdasarkan RPP yang telah disusun pada tahap perencanaan.Siklus I pertemuan ke 1 dilaksanakan pada hari Selasa, 27 Agustus 2019 dengan materi pokok tentang pengertian gaya, jenis-jenis gaya, simbol gaya, penjumlahan gaya. Pertemuan ke 2 dilaksanakan pada hari Jumat tanggal 30 Agustus 2019 dengan materi pokok pengertian usaha, rumus usaha, dan besar usaha jika dilihat dari arah gaya dan arah perpindahannya .

Berdasarkan hasil pengamatan selama kegiatan berlangsung ditemukan beberapa hubungan sebagai berikut.

1. Pada saat berpikir sendiri (proses Think), siswa kelihatan kebingungan. Mereka cenderung untuk langsung bertanya dengan temannya. Jadi diperlukan pendampingan dari guru.

2. Pada saat melakukan tes tidak ditemui siswa yang membuka buku, tapi ada siswa yang berusaha curang dengan mencontoh pekerjaan temannya, tapi hal itu tidak sampai terjadi karena ketahuan guru dan oleh guru itu langsung ditegur.

Jadi secara keseluruhan berdasarkan pengamatan selama kegiatan pembelajaran berlangsung, terlihat bahwa siswa senang bekerja sama dan aktif dalam berdiskusi, daripada berpikir sendiri (Think). Berdasarkan data hasil observasi pengamatan aktivitas guru pada siklus I pertemuan ke 1, jumlah skor yang diperoleh adalah 10 dan jumlah skor maksimal adalah 14. jadi persentase nilai rata-rata adalah $71,43 \%$. Dari hasil nilai presentase dapat diketahui bahwa aktivitas guru termasuk dalam kategori cukup. Beberapa indikator tidak dilakukan oleh guru karena waktunya sempit.

Berdasarkan data hasil observasi pengamat pada siklus I pertemuan ke 2, jumlah skor yang diperoleh adalah 11 dan jumlah skor maksimal adalah 14. jadi persentase nilai rata-rata adalah $78,57 \%$. Dari hasil nilai presentase dapat diketahui bahwa aktivitas guru termasuk dalam kategori cukup, tapi sudah ada peningkatan untuk indikator 7, yaitu guru menyediakan sumber belajar

Hasil observasi siklus I pertemuan ke 1 terhadap aktivitas siswa yang dilakukan oleh kedua pengamat adalah sebagai berikut. Skor yang diperoleh adalah 11 dan jumlah skor maksimal adalah 14. jadi jumlah nilai rata-rata pada aktivitas siswa adalah $71,43 \%$. Jadi taraf keberhasilan pada aktivitas siswa adalah cukup.

Hasil observasi terhadap aktivitas siswa pada siklus I pertemuan ke 2 yang dilakukan oleh pengamat adalah sebagai berikut. Skor yang diperoleh adalah 12 dan jumlah skor maksimal adalah 14. jadi jumlah nilai rata-rata pada aktivitas siswa adalah $85,713 \%$. Jadi taraf keberhasilan pada aktivitas siswa adalah baik.

Hasil catatan lapangan yang dilakukan adalah untuk mengetahui hal-hal penting yang terjadi selama pelaksanaan tindakan I berlangsung. Untuk lebih jelasnya hasil catatan lapangan dapat diketahui sebagai berikut.

1. Pada saat proses diskusi suasana kelas sedikit ramai karena siswanya ada yang serius mengerjakan tugas tetapi ada juga yang ngomong sendiri.

2. Diawal siswa belum memperhatikan tujuan pembelajaran. Tapi pada pertemuan berikutnya sudah memperhatikan.

3. Pada pertemuan ke 1 siswa sebagian besar belum mengkaji materi secara individu (Think), maunya langsung diskusi dengan pasangannya. Tapi pada pertemua ke 2 hal ini sudah jarang ditemui.

4. Pada saat sharing, masih ada siswa yang tidak mau bertanya dan tidak mau menjawab pertanyaan karena malu dan kurang percaya diri. Dan 
ketika menyampaikan hasil Share dengan teman di depan kelas, mereka membacanya sambil mukanya ditutupi dengan buku.

Sedangkan hasil tes dapat dikataka secara klasikal belum mengalami ketuntasan belajar, karena siswa yang mengalami tuntas belajar sebanyak 19 anak $(55,88 \%)$

Berdasarkan analisis kedua pengamat terhadap aktivitas guru dan siswa dalam pembelajaran menunjukkan taraf keberhasilan yang sangat cukup. Selama kegiatan pembelajaran dan diskusi dalam tindakan I, peneliti mendapat gambaran bahwa sebagian siswa antusias mengikuti pelajaran yang diberikan oleh guru tetapi mereka enggan untuk berpikir sendiri dulu, siswa aktif dalam mengikuti proses diskusi dengan pasangannya. Pada awalnya sharing berjalan kurang lancar karena siswa masih kurang percaya diri dalam menyampaikan pendapatnya dan juga siswa masih banyak yang malu-malu dalam melakukan sharing. Hal inilah yang membuat guru dituntut untuk dapat menumbuhkan rasa percaya diri siswa, sehingga proses sharing dapat berlangsung dengan baik.

Berdasarkan tes yang dilakukan oleh guru dapat diketahui bahwa nilai siswa meningkat, ini dapat diketahui dari skor nilai yang diperoleh. Dalam tindakan I ini peneliti menyimpulkan bahwa proses pelaksanaan pembelajaran kooperatif model Think Pair Share bisa berjalan dengan cukup baik meskipun ada hal-hal yang membuat pembelajaran terhambat itu dikarenakan suasana kelas yang ramai dan juga adanya siswa yang masih kurang percaya diri dan malu-malu pada saat proses sharing berlangsung. Tapi itu tidak masalah karena memang hal itu sering terjadi. Hal itulah yang membuat guru harus lebih menekankan pada proses pengelolaan kelas dan percaya diri siswa agar nantinya pada saat sharing kejadian seperti itu tidak terulang lagi

\section{Paparan data siklus II}

Kegiatan pembelajaran pada siklus II ini berlangsung dua minggu kemudian setelah pelaksanaan siklus I karena sistem blok dan berlangsung 2 kali pertemuan dengan alokasi waktu setiap pertemuan 3 × 45 menit. Pada pelaksanaan pembelajaran, peneliti dan teman guru bertindak sebagai fasilitator dan mediator sesuai dengan belajar kooperatif model Think Pair Share.

Berdasarkan hasil pengamatan selama kegiatan pembelajaran berlangsung terlihat siswa sangat senang dalam belajar. Sosialisasi siswa dalam berdiskusi sudah baik dan meningkat. Hasil observasi pengamat terhadap aktivitas guru dan siswa dapat diketahui bahwa persentase nilai rata-rata adalah $100 \%$. Hal ini menunjukkan bahwa taraf keberhasilan yang dilakukan oleh guru berdasarkan observasi yang dilakukan oleh pengamat termasuk dalam kategori sangat baik.

Hasil observasi terhadap aktivitas siswa berdasarkan pengamatan yang dilakukan oleh kedua pengamat adalah dalam kategori sangat baik. Pada siklus II pertemuan ke 1 masih ada siswa yang tidak memperhatikan pada saat pemantapan, tetapi pada pertemuan ke 2 hal itu sudah tidak tampak.

Catatan lapangan dibuat oleh peneliti untuk mengetahui dan mencatat hal-hal penting selama pelaksanaan tindakan berlangsung. Hasil catatan lapangan yang diperoleh adalah sebagai berikut.

a) Pada saat diskusi kelompok terlihat siswa sudah aktif dalam melakukan diskusi, meskipun masih ada beberapa siswa yang terlihat malu-malu dan kurang percaya diri.

b) Pada saat mengerjakan tes siswa terlihat sangat teratur dalam menjawab setiap soal, dan suasana kelas terlihat sangat tenang.

Refleksi pada tindakan II ini dilakukan untuk mengetahui apakah tindakan II berhasil atau belum. Apabila tindakan II ini belum berhasil maka penelitian akan dilaksanakan pada siklus berikutnya. Berdasarkan terhadap aktivitas guru dan siswa dalam proses pembelajaran maka dapat diketahui bahwa aktivitas yang dilakukan oleh siswa dan guru menunjukkan taraf keberhasilan yang sangat baik. Selain itu taraf 
keberhasilan yang dicapai dalam hal ketrampilan kooperatif siswa juga mencapai tingkat keberhasilan yang sangat memuaskan. Selama kegiatan pembelajaran dan diskusi dalam tindakan II, peneliti memperoleh gambaran antara lain: (1) sebagian siswa sangat antusias mengikuti pelajaran yang diberikan guru dan aktif dalam berdiskusi. (2) sebagian siswa mencatat dan mendengarkan penjelasan dari guru atau teman dalam berdiskusi, meskipun hal itu hanya dilakukan oleh beberapa siswa. Dari kejadian ini maka peran guru sangat dituntut untuk dapat mengelola kelas dengan baik dan dituntut untuk dapat menciptakan suasana kelas yang tenang sehingga pembelajaran dapat berjalan dengan baik.

Dari hasil pengamatan yang telah dilakukan dapat diketahui bahwa diskusi kelas/sharing kurang berjalan dengan efektif hal ini dikarenakan siswa kurang percaya diri dalam menjawab pertanyaan selain itu juga adanya siswa yang masih malu-malu dalam pelaksanaan diskusi. Dalam pelaksanaan tes, pengamat tidak menemukan siswa yang curang dalam mengerjakan soal-soal yang diberikan guru. Hasil dari tes yang diberikan oleh guru dapat diketahui bahwa nilai yang diperoleh siswa mengalami peningkatan, dapat dilihat pada siklus I tingkat ketuntasan belajar $55,88 \%$ menjadi $91,18 \%$ pada siklus II. Salah satunya adalah siswa inklusi, dimana kemampuannya tidak sama dengan siswa yang lainnya.

Beberapa temuan penalitian yang diperoleh oleh peneliti dalam pelaksanaan tindakan I dan tindakan II adalah sebagai berikut: (1) Kesiapan guru dalam pelaksanaan pembelajaran sudah cukup matang, hal ini dapat dilihat dari persiapan guru sebelum mengajar dikelas. Sebelum mengajar dikelas guru terlebih dahulu membuat rancangan pembelajaran yang akan disampaikan didalam kelas sebelum masuk kelas jauh hari sebelumnya. Hal lain yang dilakukan oleh guru sebelum pelaksanaan pembelajaran adalah guru mempersiapkan media yang akan dibutuhkan pada saat proses pembelajaran. Hal ini dilakukan untuk lebih mempermudah siswa dalam belajar, mengingat waktu yang tersedia juga terbatas maka guru berusaha memanfaatkan waktu dengan baik dengan cara mempersiapkan semuanya diawal, sehingga pada saat pembelajaran, hanya tinggal penerapannya saja. (2) Respon siswa dalam pembelajaran mata pelajaran IPA Terapan dengan menggunakan sistem pembelajaran kooperatif model Think Pair Share sangat positif. Hal ini sesuai dengan hasil analisis angket yang dibagikan oleh peneliti kepada siswa. Hasil analisis menyatakan bahwa sebagian besar siswa senang belajar dengan menggunakan kooperatif model Think Pair Share. Para siswa merasa belajar dengan menggunakan kooperatif model Think Pair Share dapat membuat mereka mempunyai waktu untuk berfikir, lebih berani dalam mengungkapkan pendapatnya tanpa ada perasaan takut, dan juga mereka merasa lebih percaya diri dalam mengerjakan tugas, selain itu mereka juga dapat belajar berinteraksi atau bersosialisasi dengan yang lain. Selain rasa senang terhadap pembelajaran ini siswa juga merasa puas dengan hasil yang mereka peroleh setelah melakukan belajar dengan menggunakan kooperatif model Think Pair Share. Model pembelajaran kooperatif model Think Pair Share ini juga dapat mengurangi rasa rendah diri karena mereka merasa dirinya mempunyai kelebihan serta keahlian yang tidak dimiliki oleh teman lainnya. Siswa mempunyai kebebasan bertanya pada teman lainnya.

Berdasarkan observasi yang dilakukan peneliti, metode pembelajaran yang sering digunakan oleh guru dalam mengajar pelajaran mata pelajaran IPA Terapan adalah dengan menggunakan metode konvensional atau metode ceramah dan mencatat. Meskipun dalam sekolah itu sudah diterapkan model KBK salah satunya adalah model Think Pair Share, tetapi dalam penerapannya guru masih belum menerapkan sepenuhnya dan guru hanya sekedar memperkenalkan saja pada siswa.

\section{KESIMPULAN}

Pembelajaran mata pelajaran IPA Terapan ini mulai dilaksanakan dengan menggunakan model pembelajaran Think Pair Share. Pelaksanaan Tindakan Kelas ini menerapkan model Think Pair Share dengan aktivitas yaitu (a) membaca, (b) berfikir 
(c) sharing, dan (d) tes. Ada peningkatan prestasi belajar materi gaya, usaha, dan energi setelah melakukan pembelajaran dengan model Think Pair Share (TPS), dimana pada siklus I tingkat ketuntasan belajar hanya mencapai 55,88 \% dan pada siklus II naik mencapai $91,18 \%$. Selain itu aktivitas guru maupun siswa mengalami peningkatan yang sebelumnya berkategori cukup menjadi sangat baik.

\section{DAFTAR RUJUKAN}

Akbar, Sa'dun. 2009. Penelitian Tindakan Kelas: Filosofi, Metodologi \& Implementasi. Yogyakarta: Cipta Media Aksara.

Arifin, Z. 2009. Evaluasi Pembelajaran: Prinsip Teknik Prosedur. Bandung: Remaja Rosdakarya.

Hanafiah, N. \& Suhana, C. 2010. Konsep strategi pembelajaran. Bandung: Refika Aditama

Iskandar, S. M. 1996. Pendidikan IImu Pengetahuan Alam. Jakarta: Depdikbud.

Ibrahim, M., dan Nur, M., 2000. Pengajaran Berdasarkan Masalah. Surabaya: University Press.

Moleong. 2007. Metodologi Penelitian Kualitatif. Bandung: PT Remaja Rosdyakarya.

Nurhadi dan Senduk, A.G. 2004. Pembelajaran Kontekstual dan Penerapannya dalam KBK. Malang. Penerbit Universitas Negeri Malang

Sagala, Saiful, 2004. Konsep Dan Makna Pembelajaran. Jakarta: Alfabeta

Somatowa, U. 2006. Bagaimana Membelajarkan IPAdi Sekolah Dasar. Jakarta: Departemen Pendidikan Nasional.

Sanjaya, W. 2009. Strategi Pembelajaran Berorientasi Standar Proses Pendidikan. Jakarta: Prenada Media

Wardhani, I. \& Wihardit, K. 2010. Penelitian Tindakan Kelas. Tangerang Selatan: Universitas Terbuka.

Wiriaatmadja, R. 2014. Metode Penelitian Tindakan Kelas untuk Meningkatkan Kinerja Guru dan Dosen. Bandung: Remaja Rosdakarya.

Tim Pelatih Proyek PGSM. 1999. Penelitian Tindakan Kelas. Jakarta: Depdikbud. https://www.asikbelajar.com/model-pembelajaran-think-pair-share-tps/ http://fatkhan.web.id/langkah-langkah-model-pembelajaran-think-pair-share/ https://biologirendy.blogspot.com/2017/08/penggunaan-model-pembelajaran-tpsthink.html

http://abdulgopuroke.blogspot.com/2017/02/model-pembelajaran-tps-think-pairshare.html 